\title{
MULTIDRUG RESISTANCE AND INTEGRONS IN ESCHERICHIA COLI ISOLATED FROM FOOD-PRODUCING ANIMALS IN SAUDI ARABIA
}

\author{
SABRY A. HASSAN ${ }^{* * * *}$ \\ * Biology Department, Faculty of Science, Taif University 888, Taif, Saudi Arabia. \\ *** Microbiology Department, Faculty of Veterinary Medicine, South Valley University 83523, Qena, Egypt. \\ Email: sabryh@1ycos.com \\ Assiut University web-site: www.aun.edu.eg
}

\section{ABSTRACT}

Received at: 20/9/2015

Accepted: 18/10/2015
Transference of antimicrobial resistance gene determinants by integrons is one of the important factors that can contribute to the increase in multidrug-resistant bacteria. The present study aimed to investigate 56 strains of animal-derived E. coli strains obtained from fecal materials of slaughtered food animals for their resistance to commonly used antimicrobial agents for presence of integrons and detection of mercury reductase gene (MerA) as indicative for presence of transposons. Multidrug resistance (MDR) was found in $38(68 \%)$ of the strains as indicated by disk diffusion method. The most frequent resistance patterns was to Ampicillin, Sulfonamides, Nalidixic acid, Cephalosporin's, Tetracycline, and Aamoxicillin/Clavulanic acid. None of tested strains were resistant to Cefepime or Imipenem. The polymerase chain reaction (PCR) results showed the presence of integrons in $26(68.4 \%)$ of MDR strains tested as well as the mercury resistance gene in $12(46.2 \%)$ of strains with integrons, indicating the role of Tn21 transposon in dissemination of the integrons and their gene cassettes within the samples studied. Our results showed high resistance rate of $E$. coli from food animals to routine antibiotics and indicate that integrons and transposon are common among MDR isolates of food producing isolates in Saudi Arabia.

Key words: multidrug resistance, integrons, transposons, Animal-derived E. coli, PCR

\section{INTRODUCTION}

Antibiotic resistance is a threat for therapy failure in human medicine. The use of antimicrobial substances in animal husbandry is considered the most important factor for debate due to its possible implications on emergence, selection and dissemination of resistant bacteria from food animals to human (Threlfall et al., 1993; Johnston, 1998).

One of the most recent adopted actions worldwide is to control and analyze the antibiotic resistance in individual countries, it is necessary to have adequate control systems which would integrate the data concerning antibiotic resistance of bacteria isolated from animals. The acquired resistance should be controlled not only in pathogenic bacteria, but also in the endogenous microflora of exposed animals and humans (Miles et al., 2006). The majority of resistance genes encoding a wide variety of resistance mechanisms are carried by mobile genetic elements such as integrons, transposons, plasmids (Iyer et al., 2013) which favors the transfer of MDR genotypes between commensals and pathogens, animals and humans.

Multi-drug resistance (MDR) in intestinal bacteria such as Escherichia coli is a major healthcare problem worldwide (Lockhart et al., 2007) and known to be associated with integrons (Leversteinvan Hall et al., 2003). Integrons are genetic structures capable of integrating or mobilizing gene cassettes encoding antibiotic resistance determinants (Carattoli, 2001). Although integrons are not mobile, they can be transferred between bacteria by transposons or plasmids in which they are present. Accordingly, integrons are a major mechanism for the spread of multidrug resistance from both clinical isolates and normal flora of food animals, as well as in human clinical specimens (Goldstein et al., 2001). Three types of integrons, each with different int genes have been identified (intI1, intI2, and intI3) that are known to be associated with antibiotic resistance (Mazel, 2006).

Several studies have investigated prevalence of integrons in MDR E. coli isolates around the world 
(Bass et al., 1999; Chang et al., 2000; Goldstein et al., 2001; Johnson et al., 2005; Kang et al., 2005; Idrees et al., 2011; De la Torre et al., 2014). However, no publicized information is available on detection of integrons in MDR isolates of E. coli from animals in Saudi Arabia. The aim of this study was to define the current prevalence and phenotypes of multi-drug resistant $E$. coli isolated from intestinal contents of food-producing animals at slaughtering in Saudi Arabia and to investigate associations between multi-drug resistance and existence of integrons as well as transposon.

\section{MATERIALS and METHODS}

\section{Collection of samples}

A total of seventy-nine samples of intestinal contents and/or fecal materials were collected aseptically over two months from sheep, bovines and chickens slaughtered in Taif abattoirs, Western Saudi Arabia. The samples were transported to the laboratory in icebox.

\section{Isolation and identification of $\boldsymbol{E}$. coli}

Fecal samples were resuspended in buffered peptone water (BPW). After homogenization, samples were cultured in MacConkey agar, which was incubated aerobically for $24 \mathrm{~h}$ at $37{ }^{\circ} \mathrm{C}$. The isolate identification by biochemical reactions using API 20 E system (bioMerieux, Marcy l'Etoile, France) and specific PCR amplification of the uspA gene (Chen and Griffiths, 1998). Isolates identified as E. coli were included in this study and further analysed.

\section{Antibiotic susceptibility assay}

The antibiotic resistance behavior of the isolated strains was determined on cation-adjusted MuellerHinton agar (Hi-Media) using disk diffusion method according to the standards and interpretive criteria described by Clinical and Laboratory Standards Institute (CLSI, 2013). The antibiotics studied were Ampicillin (AMP $25 \mu \mathrm{g}$ ), Cephalothin (CEF $30 \mu \mathrm{g}$ ), Cefotaxime (CTX $30 \mu \mathrm{g}$ ) and Ceftazidime (CAZ 30 $\mu \mathrm{g}$ ), Cefepime (FEP $30 \mu \mathrm{g}$ ), Aztreonam (ATM $30 \mu \mathrm{g}$ ), and Cefoxitin (FOX $30 \mu \mathrm{g}$ ), Amoxicillin/ Clavulanic acid (AMC 20/10 $\mu \mathrm{g}$ ). Imipenem (IMP $10 \mu \mathrm{g}$ ) was used to test susceptibility to carbapenems. Non- $\beta$ lactam antibiotics included Ciprofloxacin (CIP $5 \mu \mathrm{g}$ ), Sulfamethoxazole/ trimethoprim (SXT 23.75/1.25 $\mu \mathrm{g}$ ), Gentamycin (GEN $10 \mu \mathrm{g}$ ), Tetracycline (TET $30 \mu \mathrm{g}$ ) and Chloramphenicol (CHL $30 \mu \mathrm{g}$ ) and Nalidixic acid (NAL $30 \mu \mathrm{g}$ ). The quality control was performed to check the quality of medium and potency of antibiotic disks before use against some sensitive ATCC reference strains, including E. coli ATCC 25922 (beta-lactamase negative), E. coli ATCC 35218 (betalactamase positive), and $P$. aeruginosa ATCC 27853 (MicroTrol Discs; BD Diagnostics).

\section{Isolation of Genomic DNA}

Genomic DNA was isolated from E. coli by boiling method (Solberg et al., 2006). An overnight bacterial culture $(200 \mu l)$ was mixed with $800 \mu l$ of distilled water, boiled for $10 \mathrm{~min}$ and, after cooling, centrifuged for $5 \mathrm{~min}$ at $14000 \mathrm{rpm}$ and the supernatant was used as the DNA template for the PCR.

\section{Detection of integrons and transposon}

All the isolates were tested for the presence of conserved integrons of classes 1, 2 and 3 by degenerated primers and PCR protocol described by White et al., (2001). Detection of mercuric reductase gene merA, as a marker for presence of transposon Tn21, was performed by PCR amplification as recommended by Chatziefthimiou et al. (2007). Primers and PCR conditions are presented in table 1.

\section{RESULTS}

\section{The $E$. coli identification}

A total of 67 presumptive E. coli, by cultural and morphology characteristic were isolated, 56 were confirmed as $E$. coli by the specie-specific primer employing PCR assay targeting gene encoding the universal stress protein A (uspA). This PCR generates the 884-bp E. coli-specific product (Fig. 1), 32 $(57.1 \%)$ of which were isolated from chicken, 15 (27\%) from sheep, and $9(16.1 \%)$ from bovine. All the $56 \mathrm{E}$. coli isolates tested for susceptibility to antibiotics and screened for the presence of integrons and transposon.

\section{Antibiotic resistance phenotypes}

The results of in vitro susceptibility testing of all of the $E$. coli isolates from different animal sources are shown in Table 2. The most frequent antibiotic resistance prevalence by strains were for Ampicillin, Sulfamethoxazol-Trimethoprim, Nalidixic acid, Tetracycline, Cephalosporins and Amoxicillin/ Clavulanic acid. The chicken feces showed the greatest resistance prevalence. On the other hand, the samples showed lower resistance prevalence to gentamicin and ciprofloxacin. It was observed that imipenem and cefepime were the most effective antibiotics, no resistances to these antibiotics were observed.

The results showed that $38(68 \%)$ of the strains isolated from fecal material samples of different animal origins were multidrug-resistant (resistant to three or more antimicrobials), $32.1 \%$ resistant to one or two antimicrobials, and none of the strains were sensitive to all the antimicrobials studied. AMP resistance was present in approximately $78.6 \%$ of the isolates. 
Incidence of integrons and transposon

All of the isolates were screened for the presence of integrase genes intI1, intI2, and intI3, resulting in 491 bp amplicons (Fig. 2). Out of 38 multiresistant isolates, $26(68.4 \%)$ were integron-positive, while 12 (23\%) were integron-negative.
The amplification of the merA gene, which is considered a marker for the presence of transposon Tn21, resulted in a 309 bp fragment (Fig 3). Out of 26 strains carrying integrons, $12(46.2 \%)$ were positive for merA. Antibiotic resistance profiles and presence of merA in integron-positive strains are presented in Table 3.

Table 1: Primers used in this study

\begin{tabular}{|c|c|c|c|c|c|}
\hline Primer target & $\begin{array}{c}\text { Primer } \\
\text { name }\end{array}$ & Sequence (5 to 3 ) & PCR conditions & $\begin{array}{l}\text { Product } \\
\text { size (bp) }\end{array}$ & Reference \\
\hline \multirow{2}{*}{$\begin{array}{l}\text { Universal } \\
\text { stress protein } \\
\text { A (uspA) }\end{array}$} & Ec1 & CCGATACGCTGCCAATCAGT & \multirow{2}{*}{$\begin{array}{l}\text { initial denaturation at } 94^{\circ} \mathrm{C} \\
\text { for } 5 \text { min, } 30 \text { cycles of } 94^{\circ} \mathrm{C} \\
\text { for } 1 \text { min, } 55^{\circ} \mathrm{C} \text { for } 1 \text { min, } \\
\text { and } 72^{\circ} \mathrm{C} \text { for } 2 \text { min, with a } \\
\text { final extension at } 72^{\circ} \mathrm{C} \text { for } 5 \\
\text { min. }\end{array}$} & \multirow[t]{2}{*}{884} & \multirow{2}{*}{$\begin{array}{c}\text { Chen and } \\
\text { Griffiths, } \\
\text { (1998) }\end{array}$} \\
\hline & $\mathrm{Ec} 2$ & ACGCAGACCGTAAGGGCCAGAT & & & \\
\hline \multirow[b]{2}{*}{$\begin{array}{l}\text { Conserved } \\
\text { regions for } \\
\text { integrase } \\
\text { encoded } \\
\text { intI1, intI2, } \\
\text { intI3 }\end{array}$} & hep35 & TGCGGGTYAARGATBTKGATTT & \multirow{2}{*}{$\begin{array}{l}\text { Initial denaturation at } 94^{\circ} \mathrm{C} \\
\text { for } 10 \text { min, } 30 \text { cycles of } \\
94^{\circ} \mathrm{C} \text { for } 30 \mathrm{~s}, 55^{\circ} \mathrm{C} \text { for } 30 \\
\mathrm{~s} \text {, and extension at } 72^{\circ} \mathrm{C} \text { for } \\
45 \mathrm{~s} \text {, with a final extension } \\
\text { at } 72^{\circ} \mathrm{C} \text { for } 10 \mathrm{~min} \text {. }\end{array}$} & \multirow[t]{2}{*}{491} & \multirow{2}{*}{$\begin{array}{l}\text { White } \text { et al. } \\
\text { (2001) }\end{array}$} \\
\hline & hep36 & CARCACATGCGTRTARAT & & & \\
\hline \multirow{2}{*}{$\begin{array}{l}\text { Mercury } \\
\text { reductase } \\
\text { (merA) }\end{array}$} & A1s-n.F & TCCGCAAGTNGCVACBGTNGG & \multirow{2}{*}{$\begin{array}{l}\text { initial denaturation step at } \\
94^{\circ} \mathrm{C} \text { for } 5 \text { min, } 35 \text { cycles of } \\
94^{\circ} \mathrm{C} \text { for } 1 \mathrm{~min}, 62^{\circ} \mathrm{C} \text { for } 30 \\
\mathrm{~s} \text {, and } 72^{\circ} \mathrm{C} \text { for } 30 \mathrm{~s} \text {, and } \\
\text { with a final extension for } 7 \\
\text { min at } 72^{\circ} \mathrm{C}\end{array}$} & \multirow[t]{2}{*}{309} & \multirow{2}{*}{$\begin{array}{l}\text { Chatziefthimiou } \\
\text { et al. }(2007)\end{array}$} \\
\hline & merA5R & $\begin{array}{l}\text { CGCYGCRAGCTTYAAYCYYTC } \\
\text { RRCCATYGT }\end{array}$ & & & \\
\hline
\end{tabular}

Table 2: Antimicrobial resistance in E. coli strains isolated from different animal origins in Saudi Arabia

\begin{tabular}{lcccc}
\hline \multirow{2}{*}{ Antimicrobials } & \multicolumn{3}{c}{ Isolate source } \\
\cline { 2 - 5 } & $\begin{array}{c}\text { Chicken } \\
(\mathrm{n}=32)\end{array}$ & $\begin{array}{c}\text { Sheep } \\
(\mathrm{n}=15)\end{array}$ & $\begin{array}{c}\text { Bovine } \\
(\mathrm{n}=9)\end{array}$ & $\begin{array}{c}\text { Total No. }(\%) \\
(\mathrm{n}=56)\end{array}$ \\
\hline Ampicillin (AMP) & 26 & 11 & 7 & $44(78.6)$ \\
\hline Aztreonam (ATM) & 3 & 1 & 0 & $4(7.1)$ \\
\hline Amoxicillin/Clavulanic acid (AMC) & 8 & 3 & 0 & $11(19.6)$ \\
\hline Cefalothin (CEF) & 22 & 8 & 6 & $36(64.3)$ \\
\hline Cefepime (FEP) & 0 & 0 & 0 & $0(0)$ \\
\hline Cefotaxime (CTX) & 6 & 1 & 0 & $7(12.5)$ \\
\hline Cefoxitin (FOX) & 4 & 1 & 0 & $5(8.9)$ \\
\hline Ceftazidime (CAZ) & 2 & 1 & 0 & $3(5.4)$ \\
\hline Chloramphincole (CHL) & 7 & 1 & 0 & $8(14.3)$ \\
\hline Ciprofloxacin (CIP) & 1 & 0 & 0 & $1(1.8)$ \\
\hline Gentamicin (CEN) & 1 & 0 & 0 & $1(1.8)$ \\
\hline Imipenium (IMP) & 0 & 0 & 0 & $0(0)$ \\
\hline Nalidixic acid (NAL) & 22 & 6 & 2 & $30(53.6)$ \\
\hline Sulfamethoxizol-Trimethoprime (SXT) & 29 & 7 & 3 & $39(69.6)$ \\
\hline Tetracycline (TET) & 15 & 3 & 1 & $19(33.9)$ \\
\hline
\end{tabular}


Assiut Vet. Med. J. Vol. 61 No. 147 October 2015

Table 3: Antibiotic resistance profiles and presence of merA in integron-positive strains

\begin{tabular}{clcc}
\hline Strain no. & \multicolumn{1}{c}{ Resistance pattern } & Integrons & merA \\
\hline 1 & AMP, CEF, CHL, GEN, NAL, SXT & + & + \\
2 & AMP, AMC, ATM, CEF, CTX, CAZ, FOX, NAL, TET & + & - \\
3 & AMP, CEF, NAL, SXT, TET & + & + \\
5 & AMP, CEF, CTX, CHL, NAL, SXT & + & - \\
7 & AMP, NAL, SXT & + & - \\
8 & AMP, CEF, SXT, TET & + & + \\
\hline
\end{tabular}

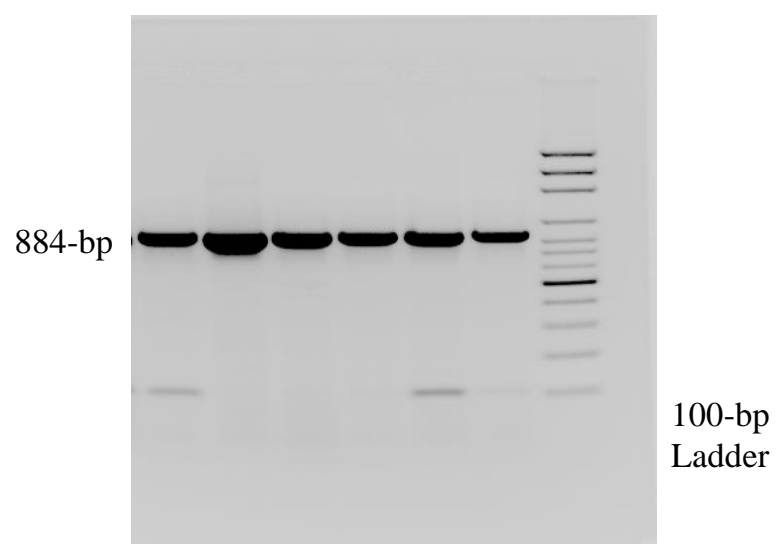

Fig. 1: The result of the PCR amplification of the DNA target gene loci of 884-bp fragment DNA region coding for universal stress protein $u s p \mathrm{~A}$.

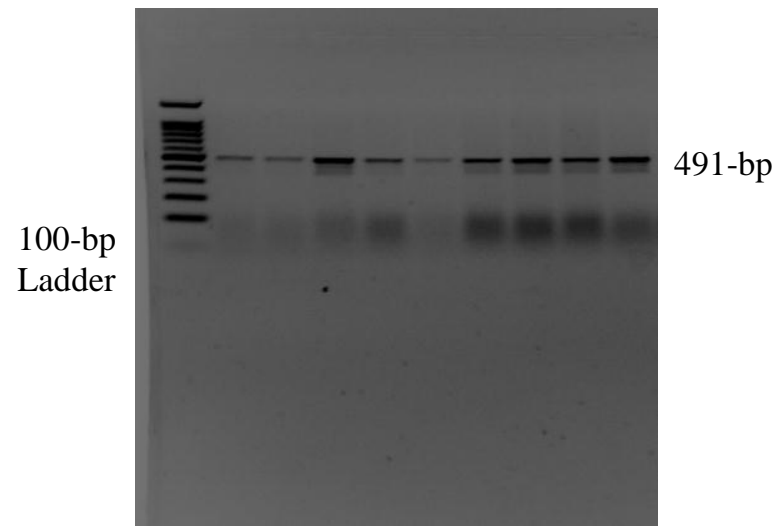

Fig. 2: The result of the PCR amplification of the DNA target gene loci of 491-bp fragment DNA coding for integrase genes intI1, intI2, and intI3.

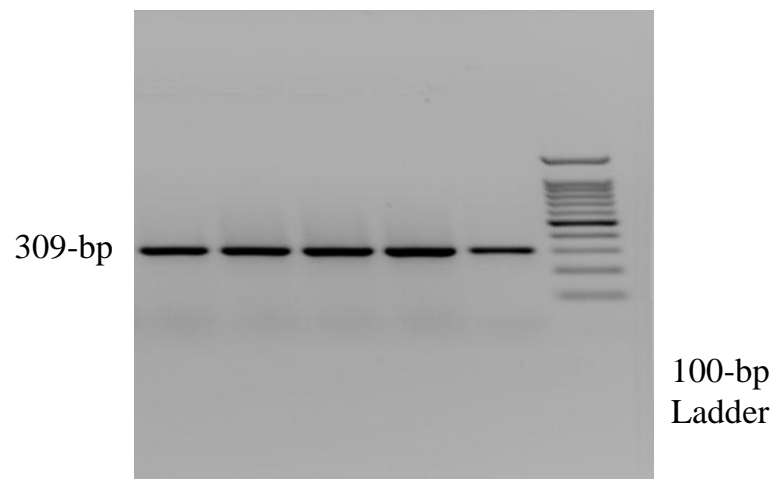

Fig. 3: The result of the PCR amplification of the DNA target gene loci of 309-bp fragment DNA region coding for mercury reductase merA 


\section{DISCUSSION}

Antimicrobial resistance of bacteria that colonize animals, especially those for food production, can have important implications to public health, as a source and reservoir of resistant bacteria which can be transferred to human. The present study investigated 56 animal-derived $E$. coli strains with respect to their resistance.

PCR for the specific differentiation of $E$. coli from other gram-negative bacteria, with primers derived from the nucleotide sequences flanking the gene encoding the universal stress protein A (usp A) (Nystrom and Neidhardt, 1992) has been described (Chen and Griffiths, 1998). This PCR generates the 884-bp E. coli-specific product and allows a rapid and specific diagnosis of $E$. coli infection.

Emergence of multidrug-resistant (MDR) bacteria has become a major public health concern worldwide, in particular, intestinal bacteria of healthy food animals, resulting in transfer of antimicrobial-resistant intestinal bacteria to humans by food products. The emergence of Escherichia coli isolates with multiple antibiotic-resistant genotypes, has been previously reported and is considered a serious health concern (Bass et al., 1999). In this study, MDR E. coli isolates with resistance to three or more different antibiotics were common. Thirty eight isolates $(68 \%)$ had MDR phenotypes. Antimicrobial resistance of commensal $E$. coli is highest in poultry, followed by sheep and veal calves. The percentage of resistance to multiple antibiotics occurring among $E$. coli isolates was lower than in other publications involving $E$. coli isolates from a variety of animal species (Lanz et al., 2003; Lim et al., 2007; Dai et al., 2008; Enne et al., 2008; Jiang et al., 2011; Knezevic and petrovic, 2008; Persoons et al., 2011, 2012).

Animal intestinal bacteria could disseminate antimicrobial-resistant genes to human intestinal bacterial flora through mobile elements like transposons and integrons (Jensen et al., 2008). Of all the $E$. coli isolates collected in our study, 26 (68.4\%) of MDR isolates were positive for integrons. It is well known that integrons carry and transfer MDR genes in bacteria in human and animals and are therefore of public health significance (Huang et al., 2012; Koo and Woo, 2012). A number of studies reported the occurrence of integrons in selected populations of gram-negative bacilli (Bass et al., 1999; Bywater et al., 2004; Saenz et al., 2004; Johnson et al., 2005), and prevalence ranging from $16 \%$ to $63 \%$ were reported by (Bass et al., 1999; Singh et al., 2005).

Furthermore, many studies have shown a correlation between the presence of integrons and multi- antibiotic resistance phenotypes in enteric bacteria (Leverstein van-Hall et al., 2003; Fluit and Schmitz, 2004; Singh et al., 2005). This has also been shown in our study.

The dissemination of integrons has been attributed to the spread of an integron-containing transposon, Tn21 (Goldstein et al., 2001; Fluit and Schmitz 2004). Tn21, a large $(19.7 \mathrm{~kb}$ ) class II replicative transposon, carries a mercury resistance (mer) operon, an integron (In2) and a transposition module (Bass et al., 1999). In addition to drug resistance, $\mathrm{Tn} 21$ confers mercury resistance through its mercuric reductase gene, merA (Bass et al., 1999). We searched for the presence of this gene in all strains containing integrons and looked into the possibility that integrons in our isolates are actually part of $\operatorname{Tn} 21$. In order to detect the presence of the merA gene encoding the enzyme responsible for mercury reduction, PCR amplification experiments using degenerate primers were performed. The gene was detected in 12 (46.2\%) of the MDR strains carrying the integrons, which indicates that at least a part of integrons spread within the strains are related to Tn21. Nevertheless, as much as about $50 \%$ of the integron-positive strains did not possess merA. One possible explanation for this finding is the presence of a truncated derivative or a Tn4, a Tn21 derivative that does not confer mercury resistance because Tn3 has inserted into and disrupted the mer locus of Tn21 (Bass et al., 1999). Mathew et al. (2009) reported identical integron amplicons in $E$. coli and Salmonella from a single livestock farm, suggesting horizontal transfer. Povilonis et al. (2010) demonstrated the existence of considerable and common pool of transferable integrons in E. coli and $S$. enteric present in clinical and livestock environment.

\section{CONCLUSION}

The present study showed high prevalence of integrons and transposon in isolates of animal-derived E. coli in Saudi Arabia and their association with multiple resistance to a range of antibiotics. These results further confirm the potential of integrons to contribute to development of resistance in E. coli. Their potential for transfer of antimicrobial resistance from bacteria of food animals to the human population is a cause of concern. It is, therefore, essential to continuously monitor bacterial susceptibility to antimicrobials and to study temporal trends among isolates from healthy animals.

\section{ACKNOWLEDGEMENTS}

The Authors are grateful for financial support of deanship of scientific research of Taif University, Saudi Arabia (project no. 1/435/3319). 


\section{DISCLOSURE STATEMENT}

No competing financial interests exist.

\section{REFERENCES}

Bass, L.; Liebert, C.A.; Lee, M.D.; Summers, A.D.; White, D.G.; Thayer, S.G. and Maurer, J.J. (1999): Incidence and characterization of integrons, genetic elements, mediating multiple-drug resistance in avian Escherichia coli. Antimicrob. Agents Chemother., 43: 2925-2929.

Bywater, R.; Deluyker, H.; Deroover, E.; de Jong, A.; Marion, H.; McConville, M.; Rowan, T.; Shryock, T.; Shuster, D.; Thomas, V.; Valle, M. and Walters, J. (2004): A European survey of antimicrobial susceptibility among zoonotic and commensal bacteria isolated from foodproducing animals. J. Antimicrob. Chemother., 54: 744-754.

Carattoli, A. (2001): Importance of integrons in the diffusion of resistance. Vet. Res., 32: 243-259.

Chang, C.Y.; Chang, L.L.; Chang, Y.H.; Lee, T.M. and Chang, S.F. (2000): Characterization of drug resistance gene cassettes associated with class 1 integrons in clinical isolates of Escherichia coli from Taiwan, ROC. J. Med. Microbiol., 49: 1097-102.

Chatziefthimiou, A.D.; Crespo-Medina, M.; Wang, Y.; Vetriani, C. and Barkay, T. (2007): The isolation and initial characterization of mercury resistant chemolithotrophic thermophilic bacteria from mercury rich geothermal springs. Etremophiles DOI 10.1007/S00792-007-0065-2.

Chen, J. and Griffiths, N.W. (1998): PCR differentiation of Escherichia coli from other gram-negative bacteria using primers derived from the nucleotide sequences flanking the gene encoding the universal stress protein. Lett. Appl. Microbiol., 27: 369-371.

Clinical and Laboratory Standards Institute (CLSI) (2013): Performance Standards for Antimicrobial Susceptibility Testing, Twentieth Informational Supplement: Supplement M100-S20, Clinical and Laboratory Standards Institute, Wayne, Pa, USA.

Dai, L.; Lu, L.M.; Wu, C.M.; Li, B.B.; Huang, S.Y.; Wang, S.C.; Qi, Y.H. and Shen, J.Z. (2008): Characterization of antimicrobial resistance among Escherichia coli isolates from chickens in China between 2001 and 2006. FEMS Microbiol. Lett., 286: 178-183.

De la Torre, E.; Colello, R.; Padola, N.L.; Etcheverría, A.; Rodríguez, E.; Amanto, F.; Tapia, M.O. and Soraci, A.L. (2014):
Detection of integrase gene in E. coli isolated from pigs at different stages of production system. Int. J. Microbiol., doi:10.1155/2014/ 489569.

Enne, V.I.; Cassar, C.; Sprigings, K.; Woodward, M.J. and Bennett, P.M. (2008): A high prevalence of antimicrobial resistant Escherichia coli isolated from pigs and a low prevalence of antimicrobial resistant $E$. coli from cattle and sheep in Great Britain at slaughter. FEMS Microbiol. Lett., 278: 193-199.

Fluit, A.C. and Schmitz, F.J. (2004): Resistance integrons and super-integrons. Clin. Microbiol. Infect. 10: 272- 288.

Goldstein, C.; Lee, M.D.; Sanchez, S.; Hudson, C.; Phillips, B.; Register, B.; Grady, M.; Liebert, C.; Summers, A.O.; White, D.G. and Maurer, J.J. (2001): Incidence of class 1 and 2 integrases in clinical and commensal bacteria from livestock, companion animals, and exotics. Antimicrob. Agents Chemother., 45: 723-726.

Huang, X.H.; Frye, J.G.; Chahine, M.A.; Glenn, L.M.; Ake, J.A.; Su, W.; Nikolich, M.P. and Lesho, E.P. (2012): Characteristics of plasmids in multidrug resistant Enterobacteriaceae isolated during prospective surveillance of a newly opened hospital in Iraq. PLoS One, 7(7): e40360.

Idrees, M.; Shah, M.A.; Michael, S.; Qamar, R. and Bokhari, M. (2011): Antimicrobial resistant Escherichia coli Strains isolated from food animals in Pakistan. Pakistan J. Zool., 43(2): 303-310.

Iyer, A.; Barbour, E.; Azhar, E.; Salabi, A.; Hassan, H.; Qadri, I.; Harakeh, S.; Alawi, M.; Na'was, T.; Abdel Nour, A.M. and Harakeh, S. (2013): Transposable elements in $E$. coli antimicrobial resistance. Adv. Biosci. Biotechnol., 4: 415423.

Jensen, L.B.; Angulo, F.J.; Molbak, K. and Wegener, H.C. (2008): Human health risks associated with antimicrobial use in animals, pp.13-26. In Guardabassi L, Jensen LB, Kruse H (eds.). Guide to Antimicrobial Use in Animals. Blackwell Publishing Ltd, Oxford, UK.

Jiang, H.X.; Lu, D.H.; Chen, Z.L.; Wang, X.M.; Chen, J.R.; Liu, Y.H.; Liao, X.P.; Liu, J.H. and Zeng, Z.L. (2011): High prevalence and widespread distribution of multi-resistant Escherichia coli isolates in pigs and poultry in China. Vet. J., 187: 99-103.

Johnson, J.R.; Kuskowski, M.A.; Smith, K.; O'Bryan, T.T. and Tatini, S. (2005): Antimicrobialresistant and extraintestinal pathogenic Escherichia coli in retail food. J. Infect. Dis., 191: 1040-1049.

Johnston, A.M. (1998): Use of antimicrobial drug in veterinary practice. BMJ., 317: 665-667. 
Kang, H.Y.; Jeong, Y.S.; Oh, J.Y.; Tae, S.H.; Choi, C.H.; Moon, D.C.; Lee, W.K.; Lee, Y.C.; Seol, S.Y.; Cho, D.T. and Lee, J.C. (2005): Characterization of antimicrobial resistance and class 1 integrons found in Escherichia coli isolates from humans and animals in Korea. J. Antimicrob. Chemother., 55: 639-644.

Knezevic, P. and Petrovic, O. (2008): Antibiotic resistance of commensal Escherichia coli of food-producing animals from three Vojvodinian farms, Serbia. Int. J. Antimicrob. Agents, 31: 360-363.

Koo, H.J. and Woo, G.J. (2012): Characterization of antimicrobial resistance of Escherichia coli recovered from foods of animal and fish origin in Korea. J. Food Protect., 75 (5): 966-972.

Lanz, R.; Kuhnert, P. and Boerlin, P. (2003): Antimicrobial resistance and resistance gene determinants in clinical Escherichia coli from different animal species in Switzerland. Vet. Microbiol., 91: 73-84.

Leverstein van-Hall, M.A.; Blok, H.E.M.; Donders, A.R.T.; Paauw, A.; Fluit, A.C. and Verhoef, J. (2003): Multidrug resistance among Enterobacteriaceae is strongly associated with the presence of integrons and is independent of species or isolate origin. J. Infect. Dis., 187: 251-259.

Lim, S.K.; Lee, H.S.; Nam, H.M.; Cho, Y.S.; Kim, J.M.; Song, S.W.; Park, Y.H. and Jung, S.C. (2007): Antimicrobial resistance observed in Escherichia coli strains isolated from fecal samples of cattle and pigs in Korea during 2003-2004. Int. J. Food Microbiol., 116: 283-286.

Lockhart, S.R.; Abramson, M.A.; Beekmann, S.E.; Gallagher, G.; Riedel, S.; Diekema, D.J.; Guinn, J.P. and Doern, G.V. (2007): Antimicrobial Resistance among GramNegative Bacilli Causing Infections in Intensive Care Unit Patients in the United States between 1993 and 2004. J. Clin. Microbiol., 45(10): 3352-3359.

Mathew, A.G.; Liamthong, S.; Lin, J. and Hong, Y. (2009): Evidence of class 1 integron transfer between Escherichia coli and Salmonella spp. on livestock farms. Foodborne Pathog. Dis. 6(8): 959-964.

Mazel, D. (2006): Integrons: agents of bacterial evolution. Nature 4: 608-620.

Miles, T.D.; McLaughlin, W. and Brown, P.D. (2006): Antimicrobial resistance of Escherichia coli isolates from broiler chickens and humans. BMC Vet. Res., 2: 7.

Nystrom, T. and Neidhardt, F.C. (1992): Cloning, mapping and nucleotide sequencing of a gene encoding a universal stress protein in Escherichia coli. Mol. Microbiol., 6: 31873198.

Persoons, D.; Bollaerts, K.; Smet, A.; Herman, L.; Heyndrickx, M.; Martel, A.; Butaye, P.; Catry, B.; Haesebrouck, F. and Dewulf, J. (2011): The importance of sample size in the determination of a flock-level antimicrobial resistance profile for Escherichia coli in broilers. Microbial Drug Resist., 17: 513-519.

Persoons, D.; Dewulf, J.; Smet, A.; Herman, L.; Heyndrickx, M.; Martel, A.; Catry, B.; Butaye, $P$. and Haesebrouck, F. (2012): Antimicrobial use in Belgian broiler production. Prev. Vet. Med., 105: 320-325.

Povilonis, J.; Šeputienè, V.; Ružauskas, M.; Šiugždiniene, R.; Virgailis, M.; Pavilonis, A. and Sužiedèlienè, E. (2010): Transferable class 1 and 2 integrons in Escherichia coli and Salmonella enterica isolates of human and animal origin in Lithuania. Foodborne Pathog. Dis., 7(10): 1185-1192.

Saenz, Y.; Brinas, L.; Dominguez, E.; Ruiz, J.; Zarazaga, M.; Vila, J. and Torres, C. (2004): Mechanisms of resistance in multipleantibiotic-resistant Escherichia coli strains of human, animal and food origins. Antimicrob. Agents Chemother., 48: 3996-4001.

Singh, R.; Schroeder, C.M.; Meng, J.; White, D.G.; McDermott, P.F.; Wagner, D.D.; Yang, H.; Simjee, S.; Debroy, C.; Walker, R.D. and Zhao, S. (2005): Identification of antimicrobial resistance and class 1 integrons in Shiga toxin-producing Escherichia coli recovered from humans and food animals. J. Antimicrob. Chemother., 56: 216- 219.

Solberg, O.D.; Ajiboye, R.M. and Riley, L.W. (2006): Origin of class I and Class II integrons and gene cassettes in a population based sample of uropathogenic Escherichia coli. J. Clin. Microbiol., 44: 1347-1351.

Threlfall, E.J.; Rowe, B. and Ward, L.R. (1993): A comparison of multiple drug resistance in Salmonellas from human and food animals in England and Wales, 1981-1990. Epidemiol. Infect., 111: 189-197.

White, P.A.; McIver, C.J. and Rawlinson, W.D. (2001): Integrons and gene cassettes in the Enterobacteriaceae. Antimicrob. Agents Chemother., 45: 2658-2661. 


\section{المقاومة المتعددة للأدوية والأنتجرونات في الأيشيريشيا القولونية المعزولة من الحيوانات المنتجة للغذاء بالمملكة العربية السعودية القولية \\ Email: sabryh@1ycos.com

\author{
صبري عبد الرجال حسن
} \\ Assiut University web-site: www.aun.edu.eg}

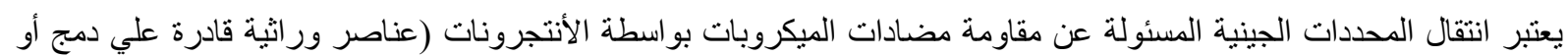

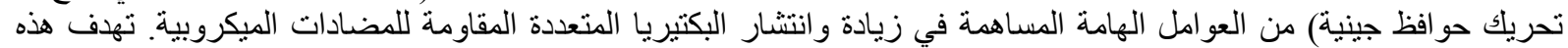

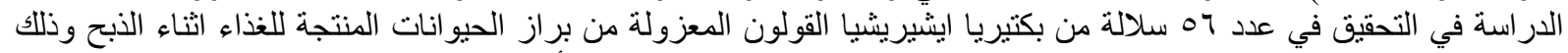

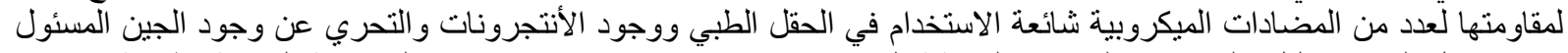

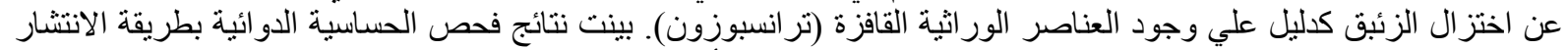

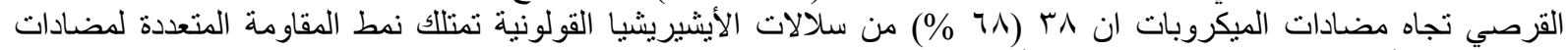

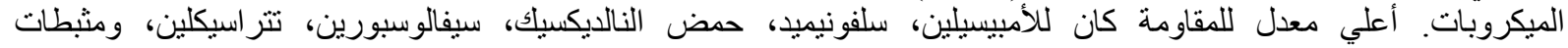

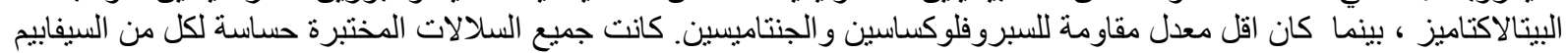

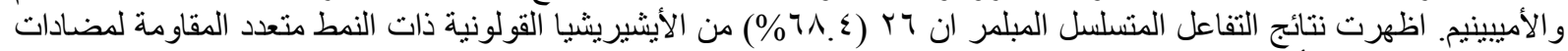

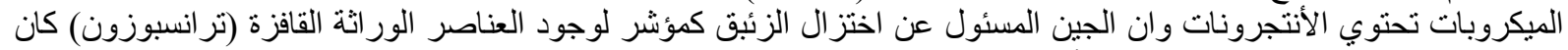

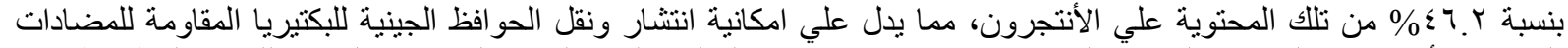
الحيوية بالأنتجرون والعناصر الور اثية القافزة بين سلالات اليشيريشيا القولون المعزولة من الحيوانات المنتجة للغذاء بالمملكة العربية 